\title{
THE COMPARISON OF BANKING SUPERVISION MODEL IN INDONESIA, UNITED KINGDOM, SOUTH KOREA AS EFORTS TO IMPROVE INDONESIAN SUPERVISION SYSTEM ${ }^{\Omega}$
}

\author{
Sulistyandari and Arief Suryono \\ Law Faculty Universitas Jenderal Soedirman \\ E-mail: sulistyandari265@yahoo.co.id
}

\begin{abstract}
This study aims to revise banking supervision by conducting comparative studies research model of banking supervision in Indonesia, the UK, South Korea and the aspirations of the respondents (Bank, OJK, theorist) in Central Java on efforts to improve banking supervision is now done in Indonesia. The results show Indonesian comparison with the UK and South Korea gives the idea that the OJK in charge of education and consumer protection to enhance its role as practiced by the FCA in the UK, and the LPS assignments need to be expanded in order to ensure that all consumers of financial institutions as was done by the FSCS in the UK and KDIC in South Korea. Aspirations of the people of the regulation and supervision of banking include aspects of regulatory, law enforcement, infrastructure, community (the Bank) and culture.
\end{abstract}

Key words: consumer, banking supervision, comparison of banking supervision.

\begin{abstract}
Abstrak
Penelitian ini bertujuan untuk memperbaiki pengawasan perbankan dengan melakukan penelitian studi banding pengawasan perbankan di Indonesia, UK, Korea Selatan dan menampung aspirasi dari para responden (Bank, OJK, Teoritisi) di Jawa Tengah mengenai upaya untuk memperbaiki pengawasan perbankan yang sekarang dilakukan di Indonesia. Hasil penelitian menunjukkan perbandingan Indonesia dengan UK dan Korea Selatan memberikan ide bahwa OJK yang membidangi edukasi dan perlindungan konsumen untuk meningkatkan perannya seperti yang dilakukan oleh FCA di UK, dan tugas LPS perlu diperluas untuk dapat menjamin semua Konsumen lembaga keuangan seperti yang dilakukan oleh FSCS di UK dan KDIC di Korea Selatan. Aspirasi masyarakat terhadap pengaturan dan pengawasan perbankan meliputi aspek regulasi, penegak hukum, sarana prasarana, masyarakat (Bank) dan kebudayaan.
\end{abstract}

Kata kunci: konsumen, pengawasan perbankan, perbandingan pengawasan perbankan.

\section{Introduction}

Based on the result of the previous year study ${ }^{1}$ showed that the banking supervision by Indonesian Bank and the law protection against bank customers normatively nowadays still found the weaknesses. Implementation of banking supervision or enforcement of banking laws against banks, especially in Central Java, which has not been fully effective. Not all customers

$\Omega \quad$ This article is the result of accelerated research professor who conducted by decree of Head of LPPM UNSOED Number: Kept. 2781/UN23.10/PN.01.00/2014.

1 Sulistyandari and Arief Suryono, Model Pengawasan Perbankan Sebagai Upaya Perlindungan Hukum Terhadap Nasabah Bank (Studi Di Jawa Tengah), Research Report, Lembaga Penelitian dan Pengabdian Kepada Masyarakat, Unsoed, Purwokerto 2013, page 58 know and understand the legal protection which is given, especially the arising rights and obligations from legislation. Model of the existing banking supervision still has the lack on its own law, the law enforcement, the community banks that applied the law and the customs of ban$\mathrm{ks}$ in conducting business activities.

According to Law No. 21 of 2011 about Financial Services Authority (in the next namely UU OJK), beginning in December 31, 2013 Bank supervision performed by the OJK along with Bank of Indonesia. Micropudential supervision is authorized by OJK and the macroprudential supervision is authorized by Bank of Indonesia. A changes in bank supervision authority (micro- 
prudential) from $\mathrm{BI}$ to the OJK aimed for the integration in the regulation and supervision of financial institutions both Bank and non-Bank, as well as bank supervision is weak by the consideration of Indonesia Bank.

The purpose of banking supervision in order to create a good banking system as a whole and individually and provide protection to the community interests. The low of bank supervision will influence the weak legal protection of bank customers and the wider community.

\section{Research Problem}

This paper discusses about: first, How are the supervision model of Bank in Indonesia, United Kingdom and South Korea as an effort to the betterment supervision of bank in Indonesia?; and second, How does the community's aspirations of the supervision and protection of the law against Bank Customers in Central Java?

\section{Research Method}

This study is a qualitative study with normative juridical and sociological juridical. The use of normative juridical is done in order to inventory and identify the valid positive law in accordance with the context of the problem in Indonesia, UK and South Korea, while the use of sociological juridical method in this study allows the researchers explore more deeply the reality in the context of the problems which is accordance with the social and cultural context form of aspiration of Trustees (FSA), the Bank and the theorist as efforts to better surveillance systems which are the law enforcement system of a banking law.

The source of this study based on secondary data and primary data. The secondary data are legislations, books, scientific journals, results of previous studies, official documents, and so on. The sources of secondary data help as a first step in studying, understanding, and analyzing the work of the legal system of banking. Primary data was obtained from the Bank, the FSA, and theorist/observer by providing a questionaire and interviews.

Central Java Province research locations taken samples of work areas based on territorial division of the FSA in Central Java, there are 4 FSA offices covering FSA Office Semarang, Solo, Purwokerto, and Tegal. Samples in this study are based on the FSA working area in Central Java Province. Then the sample/informant which are Bank and FSA are taken from 4 FSA Office area, and theorist. The study was conducted in April to September 2014. Data analysis was done based on the norms and legal theories especially banking law, administrative law and theory of law enforcement.

\section{Discussion}

Comparison Of Banking Supervision Model in Indonesia, United Kingdom and South Korea.

Authority of bank supervision in Indonesia, conducted by FSA. Supervision system which has done by FSA is an integrated surveillance system, means that the entire financial services activities carried out by various financial institutions are subject to the system of regulation and supervision of the FSA. FSA is an independent institution ${ }^{2}$ and free from interference by other parties, which has the task, function and authority of regulation, supervision and inspection of financial institutions which carrying out their activities in the financial services sector in the areas of banking, capital markets, insurance, pension funds, financial institutions and other financial institutions (banks \& non-banks). ${ }^{3}$

The integrated financial services supervision system began in Scandinavia in the middle of 1980s. Britain and Japan implement an integrated surveillance system in 1998 by establishing the United Kingdom Financial Services Authority and the Japan Financial Services Institution. ${ }^{4}$ In the financial services supervision sys-

2 Wiwin Sri Rahyani, “Independensi Otoritas Jasa Keuangan Dalam Perspektif Undang-Undang Nomor 21 Tahun 2011 Tentang Otoritas Jasa Keuangan”, Majalah Legalitas, Vol. 9 No. 3, Jakarta: Ministry of Justice and Human Rights, page 361-372; See also Magdir Ismail, "Independensi dan Profesionalisme OJK", Jurnal Hukum Bisnis, Vol. 31 No. 4, Jakarta: Business Law Development Foundation, page 405-416.

3 Nova Asmirawati, "Catatan Singkat Terhadap UndangUndang Nomor 21 Tahun 2012 Tentang Otoritas Jasa Keuangan", Majalah Legalitas, Vol.9 No.3, Jakarta: Business Law Development Foundation, page 449-558.

$4 \quad$ Zulkarnain Sitompul, "Konsepsi Dan Transformasi Otoritas Jasa Keuangan”, Majalah Legalitas, Vol.9 No.3, Ja- 
tem known today there are 5 (five) form/structure institution approach institution of the financial services sector that has been used by several countries in the world, there are the institutional approach, the functional approach, Dual systems (functional and institutional), supervision integrated agencies, and the twin peaks approach. ${ }^{5}$

Based on the result of the study data showed that the difference between Indonesia and the UK is in the form of regulatory institution structure, where in Indonesia form is an integrated supervision institution (FSA), while in the UK the British form is a twin peaks (Prudential Regulatory Authority/PRA, Financial Conduct Authority/FCA and Bank of England/BoE), ${ }^{6}$ so this brings consequences on the difference in who is authorized as the financial services supervision institution, organization structure, and duties of the supervision institution. In addition the guarantee supervision in Indonesia only guarantee a bank deposits such as demand deposits, time deposits, certificate of deposites, saving and other forms, while in UK, the FSCS (Financial Services Compensation Scheme) guarantee the deposits, insurance policies, insurance brokers, investment managers, and the mortgagee.

The equation between Indonesia and the UK is on the purpose of the formed of regulatory institutions in order to materialize the good financial institutions condition (bank and nonbank), so that the stability of the financial sys-

karta: Business Law Development Foundation, page 343 360.

5 Bintang Puwan Permata, "Persamaan dan Perbedaan Otoritas Jasa Keuangan Indonesia Dengan Financial Services Authority Inggris", Privat Law, Vol 2 No. 1, July 2013 Ed., Surakarta: UNS, page14.

6 Michael W. Taylor, "The Road From Twin Peaks And The Way Back", Connecticut Insurance Law Journal, Vol. 16, could be seen at: http://insurancejournal.org/wpcontent/uploads/2011/07, accessed on April, $11^{\text {th }} 2015$; see Bryane Michael, "The Twin Peaks Regulatary Model: The Future of Financial Regulation", Journal of Banking, Mar-Apr 2014, http://www.law.hku.hk/aiifl/wp-content/uploads/2014/09/Twin-Peaks.pdf, accessed on April, $11^{\text {th }}$ 2015; Adriane Fresh and Martin Neil Baily, "What does international experience tell us about regulatory consolidation", Journal of International Law, could be seen at: http://www.brookings.edu/ /media/ research/files/reports/2009/9/21-consolidation-baily/ 0921_consolidation_baily.pdf. page 257-307, accessed on April, 11 2015. tem will overall materialize and provide protection to customers of financial institutions. The surveillance using a risk-based approach method by direct way (on-site) and indirect way (off-site). Besides the budget of the regulatory institutions are financed from the financial services industry supervised.

Indonesia and South Korea are generally in a similar condition, as in the form of a supervision institution structure both is an integrated supervision institution, so this brings consequences of equality who is authorized as a supervision institution, the purpose of the establishment of supervision agencies, regulatory agencies's task, monitoring agencies's budget and the Central Bank's role in the supervision of financial services (banks and non-banks). The differences between Indonesia and South Korea are in the organizational structure of the FSA supervision agencies with the Financial Services Supervision (FSS), and the deposit insurance institution in Indonesia only guarantee a bank deposits in the form of demand deposits, time deposits, certificates of deposits, savings and other forms equivalent, while KDIC (Korean Deposit Insurance Corporation): guarantee deposits, bank savings, securities companies, insurance, commercial and credit unions. This is understandable, because the integrated surveillance in South Korea began in 1999, while in Indonesia just started on December 31, 2013.

There are many similiarities between Indonesia and South Korea especially in the form of the integrated supervision institution structure, therefore the FSA of Indonesia as integrated financial supervision institution which legally established by law should have the reinforcement. Based on the historical, in 2008 when the world experienced a global financial crisis, in which a large country such as the USA, UK, US, but Korea through the FSS (integrated supervision institution) had a better condition than others. FSS big test in Korea appeared in 2011 when the 11 (eleven) Bank Saving was closed so its detriment many depostmans and investors, it showed the interest of Korea to change the structure of the integrated supervision institution with the Twin Peaks model, it is inte- 
grated supervision institution model which separates the regulation function between the one who perform the prudential regulation and another who focused on the business of the regulation. With the Twin Peaks model, the customers and the investors will get better protection, this integrated supervision institution model has been applied by developed countries such as USA, UK Britain. ${ }^{7}$

Based on the UK Britain historically, since 1998, the form of the supervision institution structure already implemented the integrated supervision institution, with the FSA (Financial Services Authority), but tripartite regulation between HM Treasury, the BoE and the FSA are failed to detect and deal the financial crisis in global financial crisis in 2008. Finally, BoE still lead the authority to resolve those banks failed. Therefore, in 2010 in England there was a debate between democrat liberal parties which wants FSA maintained because it will make an instability in the sensitive financial system, but on the other hand the conservatives who supported by public opinion wants to disperse the FSA in order to build surveillance systems which is oriented on the purpose of putting the BoE (Bank Central) as the center of the financial supervision system in England, and in the end the government decided to dissolve the FSA and establish PRA and FCA also FPC (Financial Policy Commission) which are subsidiary of the BoE. Yong Woo Lee found the fact in England is difficult to judge which system is better. As a lesson that a financial control system in a particular country are determined by global trends in the financial markets, the country's historical background, social traditions, economic characteristics, and political factors. Therefore, it is unreasonable to find the suitable model of each country. Finally, when one particular system is adopted, it is absolutely necessary to maximize profits and minimize losses, and make the system which induces the expected results from time to time. The IMF showed, failure of the fi-

7 You Kyung Huh, 2013, The structure of Fnancial Supervision in Korea after The Global Financial Crisis: Focus on Consumer Protection, International Finance, Seminar LL.M. Program, Harvard Law School, page 14-15. nancial institution does not mean the failure of financial institutions supervision system. In addition, Taylor argues that it need to keep in mind that politicians tend to change the structure of supervision after the crisis to create the perception that they are dealing with a problem. ${ }^{8}$

Based on the comparison of financial supervision institution system between Indonesia and Korea, in this study it would not suggested to adopt the twin peaks model of supervision in England, but rather to strengthen the monitoring system which is now implemented in Indonesia it is implement things from both countries to maximize profits by regulate the behavior of financial firms to ensure that costumers get a fair protection from financial companies, which in England this task was done by an individual institution named FCA, but in Indonesia it was done by the FSA. In the organizational structure of the FSA there is a special member of the Board of Commissioners who handles education and consumer protection, but this role needs to be improved, as was done by the FCA. In addition the task of the Deposit Insurance Institution (LPS) needs to be expanded not only guarantee bank deposits only, but also guarantees deposits, insurance policies, insurance brokers, investment managers, mortgage, and KDIC (Korea Deposit Insurance Corporation) in Korea which guarantee deposits and savings banks, securities companies, insurance, commercial and credit unions, as carried out by the FSCS (Financial Services Compensation Scheme) in England, so banks and non-bank's integrated financial services supervision institutions in the FSA can provide legal protection to all consumers of financial services. ${ }^{9}$ Besides the principles of effective banking supervision (The Core Principles for Effective Bank Supervision) which

8 Yong-Woo Lee, "International Finance The Break up of The UK Financial Service Authority and The Implication", Capital Market Perspecive e-Journal, Vol. 4, No 2, 2012, Korea: Capital Market Institute, page 66.

9 Kam Hon Cu, "Deposit Insurance and Banking Stability", Cato Journal, 2011, could be seen at http://object. cato.org/sites/cato.org/files/serials/files/cato-journal/2011/1/cj31n1-7.pdf, accessed on April, 11 2015. 
issued by Bassel Committee is applied by the FSA. ${ }^{10}$

\section{Societies Aspiration of Supervision and Bank Customer's Legal Protection in Central Java}

In a study of law administrative, supervision is a part of the law enforcement aspect which instrument are: monitoring and punishment. Supervision was conducted on compliance of the community members so that the mandatory provisions or the prohibited provisions are not violated. Punishment was also a pressure instrument, therefore the establishment of rules which have punishment should be done by an institution which has the authority to make laws and regulations (Algemen Verbinden de Voorschrijjten).

According to Soeryono Soekanto, conceptually, the core and the meaning of the rule of law lies in harmonizing the relations of activities that explained in the hierarchy of values in norms and attitudes manifest steady and acts as a series of translation of the value of the final stage, to create, maintain, and keep the social peace life. The main problem of law enforcement actually located on the factors that may affected it. Those factors are as follows: factor of its own law; law enforcement factors, which are the parties who formed or applied the law; facilities to support the enforcement of law; community factors, which is the environment in where the law is applicable or applied; cultural factors, which as a result of creative works, and the feel based on human initiative in social life. Those five factors are closely interrelated and its the essence of law enforcement, is also a measure of the effectiveness of law enforcement. These factors have a neutral meaning, so that a positive or negative impact lies in the

10 Gerard Caprio, Jr, "Financial Regulation After The Crisis: How Did We Get Here and How Do Get Out", Journal of Financial Special Paper, Nov 2013, ISSN 13599151-226, could be seen at: http://www.lse.ac.uk/ fmg/workingPapers/specialPapers/PDF/sp226.pdf, diakses pada tanggal April, $13^{\text {th }}$ 2015.; see Michael Barr and Geoffrey P. Miller, "Global Administrative Law: The View From Basel", European Journal of International Law, Vol. 17, could be seen at: http://ejil.oxfordjournals.org/content/17/1/15. full, accessed on April, $13^{\text {th }}$ 2015. content of these factors. ${ }^{11}$ Aspirations of people towards banking supervision (banking law enforcement) in this study will be analyzed based on five (5) factors which are affecting the banking supervision towards the tought of Soerjono Soekanto above, and aspirations from the society in this study were taken by FSA (supervision), Bank, and the theorists.

First, the legal factor. The meaning of law is generally acceptable written regulations made by the legitimate authority. In this study, it such as the Banking Law, BI Law, FSA Law, BI Regulation, the FSA Rules. The data based on data bank's aspiration, that the FSA should involving the Bank in order to make a regulations, so that the rules can be run. In making a regulations there is a balance protection between the Bank and Consumer after the regulations socialized intensively. Aspirations Data of the FSA, mentioned that the regulatory capital for BPR needs to be change, such as the capital for BPR amounting to 2 (two) billion needs to be reviewed in order there was an existing developments. GCG (Good Corporate Governance) Regulations and management needs to be applied to the BPR. Aspirations Data of theorists/observer, mentioned that in the terms of the regulation, the FSA challenge is not equivalent with the form of governing financial institutions subject to the jurisdiction regulations of the FSA. Some financial institutions have been set up in the form of legislation, such as banking, capital markets, insurance, while most of the financial institutions are still arranged in the form of regulations under the legislation. Ideally, all the financial institutions regulated by law because its related with the public interest. FSA's future huge task is to develop an RUU which covers all the financial institutions that become the object of the FSA supervision. It is necessary to create equality of basic principles which applied to all financial institutions.

Second, law eforcement factors. Based on the research of banking supervision or the enforcement of banking laws are very influenced

11 Soerjono Soekanto, 2011, Faktor-Faktor yang Mempengaruhi Penegakan Hukum, Jakarta: PT Raja Grafindo Persada, page 5-9. 
by law enforcement itself. Referred to in this study are parties who form and apply the law, which is directly involved in the enforcement of banking laws, which are now carried out by FSA (starting December 31, 2013), which previously conducted by the Bl. Factors that affect law enforcement in banking law enforcement are the independence of the FSA and the FSA's role as integrated financial supervision institution.

Regarding to the FSA independence, based on aspiration data of the FSA, although FSA as financial services supervision institution which budget comes from the APBN and levies of financial institutions supervised, as derived from licensing fees, the establishment of the bank, and the contribution of financial services institutions supervised, but the FSA stated that it remains as an independent institution. Meanwhile the aspiration data of theorists said that the FSA independences will be fully effective, if there is a Good Corporate Governance (GCG) in the world of finance and banking, and there are clear regulations concerning the independence of institutions and budgets.

Regarding to the FSA as an integrated financial services institution, means that the entire financial services activities carried out by various financial institutions are subject to FSA regulation and supervision system. Based on data from the aspirations of the FSA said that the concept of integrated supervision by the FSA to date has not been established, so it needs to get a clear concept. While the aspirations of the theorist says that the need to be integrated is: the authority to issue regulations that are owned by the FSA include banking regulation, capital markets, insurance and LKBB are expected to be created equality among financial institutions that are under control of FSA; investigative authority possessed by the FSA is expected to handle all crime in the financial sector can be done by one institution, its the FSA; consumer protection, should be considered that the overall dispute between the consumer and the financial institution subject to the specific dispute resolution institutions; rescue and liquidation of banks and other financial institutions. The expansion authority of LPS needs to be consider include the liquidation and rescue as well as non-bank customers insurance. This is to avoid if there are different regimes among financial institutions.

Third, facilities and infrastructure factors. Based on the study data showed that Human Resources (HR) factors have a big affects to the supervisors in the supervision of banking or banking law enforcement, in addition to other factors such as surveillance methods and approaches in supervision. Therefore there are following aspirations of Bank, FSA and theorist/ observer in this regard.

Regarding to FSA Human Resources. Based on the bank aspiration that all HR supervisor should dominate and determine the application of the rules, all HR supervisor should have the same perception of the rules, and in the examination of HR supervisor should have knowledge of the field and not too theoretical, so that the application of the rules are not rigid. Based on data from the aspirations of the FSA said that the ability of the FSA Supervisory competence of human resources for financial institutions Bank and non-Bank needs to be improved, because time becomes supervisor $\mathrm{BI}$, each bank supervisors must have a certification level 1 to 7 . The quantity of HR Supervisors need to be added as such in the FSA Office Tegal supervisor ratio with Bank supervised 1:11. Based on data from the aspirations of the theo-rist said that there needs to be professionalism and integrity of the HR supervisor FSA.

Surveillance methods which is conducted by FSA are indirect and direct supervision. Based on the aspiration of the Bank said that the indirect supervision conducted through the Bank's business activity report to the FSA that must be done, where there are several kinds of monthly reports, 3 (three) months reports, BMPK reports and everything was done by on line, not all the bank clerks (BPR) mastered the Technology Information yet, so there are some BPR whose late in submitting the report, if there is a delay, the Bank will get the punishment. Therefore, the Bank recommends the allocation of funds from the FSA to the Bank as the training of human resources which ever done by $\mathrm{BI}$ 
by Bintek funds. Based on the aspiration of the FSA relates to direct supervision methods to the Bank which conducted periodically usually once a year. Examination of the Bank was done by sampling method, means that not all transactions and administration from the Bank's business activities conducted inspection, so that sometimes not all the problems in the bank detected by the concerned Supervisory, and this is a weakness of a direct examination.

Fourth, society factors, which is the environment where law was applied. The aim of this study is the bank community. Bank's knowledge and understanding of the rights and obligation, monitoring and punishment are to provide the protection to the bank itself, the customer, and society. Therefore, the knowledge and understanding of Bank influence the enforcement of the banking law. Based on the aspirations of the Bank said that before the punishment was given to the Bank related to banking supervision, the Supervisory should give a clarification on it first. While the aspirations of the FSA said that for BPR who often violate the principles of prudence and the Board of Directors of the Bank is not able to improve its performance, it is advised to replace the Board of Directors. BPR who failing to have procedures and internal control policies (SKAI, Compliance Director), Bank was urged to have it immediately. Similar with BPR who do not has infrastructure such as IT infrastructure which have to be completed soon, HR of BPR enhanced the quality by allocated $5 \%$ of the operating costs by Bank in order to improve the quality of human resources of the Bank.

Fifth, cultural factors, its actually a factor that united with the society factors, the differences in cultural factors is in the values which is more emphasis considered good (so it must be adhered to) and are considered to be bad (so it should be avoided) by the public. Values (culture) which adopted by the bank community also affect the banking law enforcement. Based on the study data showed that in conducting BPR business activities assumes that the system is proactive is the best way to get closer to customers/small people. The reason were because it wanted to ease the burden on small clients; unfulfilled target; an intense competition among banks scramble micro small customers, but the pick up the ball system which is considered to be a good can allow the violation of the rules, such as violations of the rules on lending. Hence the aspirations of the FSA said that the system is indeed pick up the ball from RB and superior service can still be done, only in the implementation of the Bank's business activities should still be in accordance with the precautionary principle.

\section{Closing \\ Coclusion}

There is no ideal model of banking supervision which is appropriate to each country. But with the comparative study of Indonesia with the UK and South Korea gives the idea that the FSA in charge of education and consumer protection to enhance its role as the role of FCA in the UK and the LPS task needs to be expanded in order to ensure that all financial institutions consumers as was done by the FSCS in the UK and KDIC in South Korea.

Society aspirations against the regulation and banking supervision are: first, there is needs to be an integration aspects of the regulation on the authority of the FSA to the arrangement, the investigation, consumer protection, rescue and liquidation of banks and other financial institutions; second, there was needs a clear regulation of law enforcement aspect about the independence of the institution and the FSA budget and the implementation of surveillance carried out effectively; third, the infrastructure aspects needs to increase its quantity, professionalism and integrity of HR Supervisor; fourth, the society aspect (the Bank) needs to understand its rights and obligations and punishment for banks that break the rules; and fifth, cultural aspects which the proactive system is a superior services by BPR but the implementation must be in accordance with the regulations.

\section{Suggestion}


OJK needs to improve its role by regulating the behavior of financial firms to ensure that the consumers get a fair protection from financial companies. There should be a regulations which governing the authority of the FSA integration of the arrangement, investigations, consumer protection, rescue and liquidation of banks and other financial institutions. A clear regulation about the independence and the FSA budget and the implementation of surveillance carried out effectively by increasing the quantity, professionalism and integrity of the FSA human resources Supervisory and strict punishment for banks that break the rules. In addition, LPS duty extended not only guarantee bank deposits, but also guarantee securities companies, insurance, and other financial institutions.

\section{Bibliography}

Barr, Michael and Geoffrey P. Miller. "Global Administrative Law: The View From Basel”. European Journal of International Law. Vol. 17. Could be seen at: http:// ejil.oxfordjournals.org/content/17/1/15. full. Accessed on, April, $13^{\text {th }} 2015$.

Caprio, Gerard Jr. "Financial Regulation After The Crisis: How Did We Get Here and How Do Get Out". Journal of Financial Special Paper. Nov 2013. ISSN 1359-9151-226. Could be seen at: http://www.lse.ac.uk/ fmg/workingPapers/specialPapers/PDF/sp 226.pdf. Accessed on, April, $13^{\text {th }}$ 2015;

$\mathrm{Cu}$, Kam Hon. "Deposit Insurance and Banking Stability". Cato Journal. 2011. Could be seen at: http://object.cato.org/sites/ cato.org/files/serials/files/cato-journal/ 2011/1/cj31n1-7.pdf. Accessed on, April, $11^{\text {th }} 2015$;

Fresh, Adriane and Martin Neil Baily. "What does international experience tell us about regulatory consolidation". Journal of International Law. Could be seen at: http://www.brookings.edu/ /media/rese arch/files/reports/2009/9/21-consolidation-baily/0921_consolidation_baily.pdf. page 257-307. Accessed on, April, $11^{\text {th }}$ 2015;

Huh, You Kyung. 2013. The structure of Financial Supervision in Korea after The Global Financial Crisis: Focus on Consumer
Protection. International Finance. Seminar LL.M. Program. Harvard Law School;

Ismail, Magdir. "Indepedensi dan Profesionalisme OJK”. Jurnal hukum Bisnis, Vol. 31 No. 4. Jakarta: Business Law Development Foundation;

Lee, Yong-Woo. "International Finance The Break up of The UK Financial Service Authority and The Implication". Capital Market Perspecive e-Journal. Vol. 4. No 2. 2012. Korea: Capital Market Institute;

Michael, Bryane. "The Twin Peaks Regulatary Model: The Future of Financial Regulation". Journal of Banking. Mar-Apr 2014. http://www.law.hku.hk/aiifl/wp-content/uploads/2014/09/Twin-Peaks.pdf . Accessed on, April, $11^{\text {th }}$ 2015;

Nova Asmirawati. "Catatan Singkat Terhadap Undang-Undang Nomor 21 Tahun 2012 Tentang Otoritas Jasa Keuangan". Majalah Litigasi. Vol.9 No.3. Jakarta: Ministry of Law and Human Rights;

Permata, Bintang Puwan. "Persamaan dan Perbedaan Otoritas Jasa Keuangan Indonesia Dengan Financial Services Authority Inggris”. Privat Law. Vol. 2 No. 1. Juy 2013 Ed., Surakarta: UNS;

Rahyani, Wiwin Sri. "Independensi Otoritas Jasa Keuangan dalam Perspektif Undang-Undang Nomor 21 Tahun 2011 Tentang Otoritas Jasa Keuangan". Majalah Lega-litas. Vol. 9 No. 3. Jakarta: Ministry of Law and Human Rights.;

Sitompul, Zulkarnain. "Konsepsi dan Transformasi Otoritas Jasa Keuangan". Majalah Legalitas. Vol. 9 No. 3. Jakarta: Ministry of Law and Human Rights.;

Soekanto, Soerjono. 2011. Faktor-Faktor Yang Mempengaruhi Penegakan Hukum. Jakarta: PT Raja Grafindo Persada;

Sulistyandari and Arief Suryono. Model Pengawasan Perbankan Sebagai Upaya Perlindungan Hukum Terhadap Nasabah Bank (Studi Di Jawa Tengah). Research Report. Purwokerto: Lembaga Penelitian dan Pengabdian Kepada Masyarakat Unsoed. 2013;

Taylor, Michael W. "The Road From Twin Peaks And The Way Back". Connecticut Insurance Law Journal. Vol. 16. Could be seen at: http://insurancejournal.org/wp-content/uploads/2011/07. Accessed on, April, 11 2015. 